\title{
Nutrients, Fiber Fraction, and In Vitro Fiber Digestibility of Brown-Midrib Sorghum Mutant Lines Affected by The Maturity Stages
}

\author{
R. Sriagtula ${ }^{\mathrm{a}, *}$, P. D. M. H. Karti ${ }^{\mathrm{b}}$, L. Abdullah ${ }^{\mathrm{b}}$, Supriyanto ${ }^{c}$, D. A. Astuti ${ }^{\mathrm{b}}$, \& Zurmiati $^{\mathrm{a}}$ \\ aDepartment of Nutrition and Feed Technology, Faculty of Animal Science, Andalas University \\ Gedung Fakultas Peternakan, Limau Manis Padang Kode Pos 25163, Indonesia \\ ${ }^{b}$ Department of Nutrition Science and Feed Technology, Faculty of Animal Science, IPB University \\ 'Department of Silviculture, Faculty of Forestry, IPB University \\ Kampus IPB Dramaga, Bogor 16680, West Java, Indonesia \\ *Corresponding author: riesisriagtula@ansci.unand.ac.id \\ (Received 01-07-2020; Revised 12-11-2020; Accepted 29-12-2020)
}

\begin{abstract}
The mutant line of Brown-midrib sorghum has lower lignin content than conventional sorghum. The objectives of this research were to investigate the effects of plant maturity stages at harvest times on nutrient, fiber fraction, tannin content, volatile fatty acids (VFA) production, and in vitro fiber digestibility of mutant lines of Brown Midrib (BMR) sorghum. This research was arranged into a complete block design with a factorial arrangement in three replications. The first factor was a line of BMR sorghum consisted of 3 levels, i.e., Patir 3.1 (non-BMR line/control), Patir 3.2 (BMR line), and Patir 3.7 (BMR line). The second factor was the generative stages of sorghum consisted of 3 levels, i.e., flowering stage, soft-dough stage, and hard-dough stage. The observed variables were nutrient, fiber fraction, tannin content, in vitro rumen fluid characteristics, VFA proportion, acetate: propionate (A:P) ratio, and in vitro fiber-fraction digestibility (IVFFD). Data were analyzed by Analysis of Variance (ANOVA) and Duncan's Multiple Range Test (DMRT). No interaction between sorghum-mutant lines and harvest time on nutrient contents, except on total digestible nutrients $(\mathrm{TDN})$, tannin, and VFA. The factor of sorghum-mutant line affected $(\mathrm{p}<0.01)$ crude protein $(\mathrm{CP})$, crude fiber (CF), acid detergent fiber (ADF), lignin, neutral detergent fiber digestibility (NDFD), $\mathrm{NH}_{3}$, butyrate, isovalerate, and valerate. Maturity stages affected dry matter (DM), $\mathrm{CF}$, ash, crude fat, fiber, and fraction, except hemicellulose, acid detergent fiber digestibility (ADFD), and NDFD, $\mathrm{NH}_{3}$ isovalerate, and valerate. Patir 3.7 at the hard-dough stage produced the highest TDN, but the highest VFA was produced by Patir 3.1 at flowering stages. BMR sorghum-mutant lines produced higher ADF digestibility than non-BMR sorghum-mutant lines. The increasing NDF digestibility was significantly influenced by both sorghum-mutant lines and maturity stages $(\mathrm{p}<0.01)$. It is concluded that BMR sorghum-mutant lines at the hard-dough stage produce better nutrient and in vitro digestibility, but the butyric acid is higher in non-BMR sorghum-mutant lines.
\end{abstract}

Keywords: ADF digestibility; BMR sorghum; NDF digestibility; propionate ratio; sorghum mutant line

\section{INTRODUCTION}

Sorghum (Sorghum bicolor L. Moench) is the most produced crop in the world after wheat, rice, maize, and barley (Dahir et al., 2015). Sorghum has a wide adaptation and low input to grow on marginal lands (Mathur et al., 2017; Sriagtula et al., 2019). Sorghum has higher lignin content, which limits its consumption by ruminant animals due to conventional varieties of sorghum used is as a food and industrial crop (Sriagtula et al., 2017). Brown-midrib sorghum-mutant line was a result of a genetic mutation that has lower lignin content. Some BMR sorghum-mutant lines are produced in Indonesia, both Patir 3.2 and Patir 3.7, and have the highest biomass productivity (Sriagtula et al., 2016). Decreasing lignin content in BMR increases digestibility, the efficiency of energy conversion, and nutrient content (Christensen \& Rasmussen, 2019).

The nutrition content and cell wall proportion of forage are directly related to the maturity stage. Advance maturity causes the increasing lignin content but with the decreased digestibility, quality of forages, and livestock productivity (Beck et al., 2013). In forages, the concentration of ADF refers to the proportion of cell walls consisting of cellulose and lignin. The NDF value refers to the total cell wall composed of the ADF and hemicellulose fractions. Lignin binds to the fiber components such as cellulose and hemicellulose and physically acts as a barrier to the process of breaking down the plant cell walls by microbial enzymes (Salama \& Nawar, 2016). The higher the forage lignin content, the more difficult the feed nutrients are to be digested. Whereas 
in the rumen, fiber produces VFA as the main energy source for ruminants. Fiber fermentation increases the acetate proportion and decreases the propionate proportion. Forages with low lignin content are expected to reduce the acetate to propionate $(\mathrm{A}: \mathrm{P})$ ratio during rumen fermentation (Rahman et al., 2013).

Many studies have reported the increased nutrient content and dry-matter digestibility (DMD) as well as organic-matter digestibility (OMD) in BMR sorghum (Li et al., 2015; Wahyono et al., 2019). However, information about ADFD and NDFD are relatively limited despite this information is more relevant to cell-wall utilization by ruminants. The observation of sorghum-mutant lines and BMR-sorghum variety in tropical countries, like Indonesia, are limited. Patir 3.2 and Patir 3.7 lines are the new generations of BMR sorghum-mutant lines in Indonesia, and their nutrient contents, fiber fraction proportions, as well as fiber digestibility as forages are needed to be evaluated. Based on those ideas, the optimum harvest times of BMR sorghum-mutant lines, Patir 3.2 and Patir 3.7 should be investigated because harvesting age has relevance to production as well as nutritional value and digestibility. Furthermore, the digestibility of ruminal organic acids and in vitro fiber fraction in different maturity stages should also be evaluated.

\section{MATERIALS AND METHODS}

The research was conducted at SEAMEO BIOTROP Bogor, Indonesia used a Completely Block Design with a factorial arrangement in three replications. The first factor was the sorghum-mutant line consisted of $3 \mathrm{lev}-$ els, i.e., Patir 3.1 (non-BMR line/control), Patir 3.2 (BMR line), and Patir 3.7 (BMR line). The second factor was a generative stage at harvesting consisted of 3 levels, i.e., flowering stage (74 days after sown/DAS), soft-dough stage (90 DAS), and hard-dough stage (110 DAS).

\section{The Culture Technique and Sample Preparation}

The technique of culturing of sorghum plant referred to Sriagtula et al. (2016). The rainfall data during the study are presented in Figure 1, which were categorized as low at $<100 \mathrm{~mm}$ to a high at $300-500 \mathrm{~mm}$ (ICCSR, 2020).

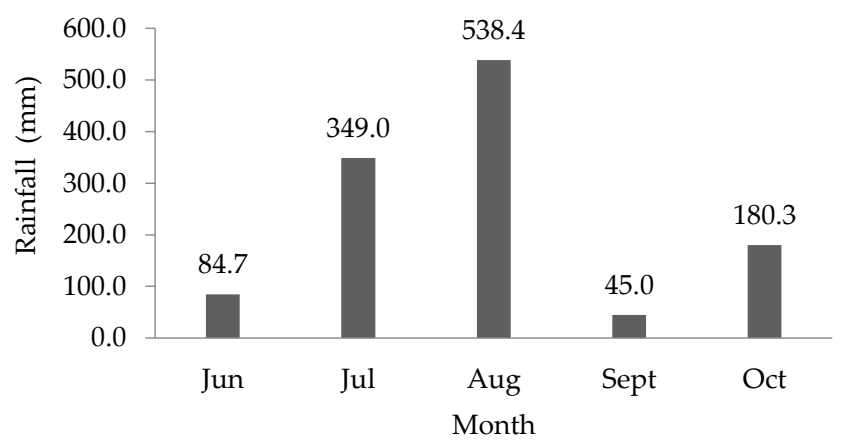

Figure 1. Climate condition during field experiment

\section{In Vitro Fiber Fraction Digestibility (IVFFD) Test}

The in vitro digestibility test was conducted by following Tilley \& Terry (1963) method. Each sample was weighed at $0.5 \mathrm{~g}$ and incubated for $48 \mathrm{~h}$ with $40 \mathrm{~mL}$ of McDougall buffer solution $+10 \mathrm{~mL}$ of rumen fluid. The anaerobic condition was achieved by $\mathrm{CO}_{2}$ flows for several minutes. The addition of 2-3 drops of $\mathrm{HgCl}_{2}$ was conducted to stop microbial activity at the end of the first fermentation, and then the inoculation period was continued for $48 \mathrm{~h}$ with the addition of $50 \mathrm{~g}$ pepsin $\mathrm{HCl}$. The rumen fluid used in this study was obtained from three rumen-fistulated adult Bali cattle fed roughage and concentrate with a ratio of 60:40. The IVFFD for each ingredient was measured in duplicate.

\section{Variables}

The observed variables were nutrient and fiberfraction content, IVFFD, in vitro rumen characteristics, VFA proportion, and A:P ratio of the whole plant of sorghum-mutant lines. The tannin content was observed in the panicle part.

\section{Chemical Analysis and Calculation}

The quality of the whole plant sorghum-mutant line was measured by proximate analysis referred to as the AOAC method (2005). Ca and P determinations were conducted by using atomic absorption spectrometry (AAS) and spectrophotometer, respectively, by using the AOAC method (2005). The analysis of fiber fraction was conducted by following the method of Van Soest (1994). TDN content was calculated by following the method of Hartadi et al. (2005). Tannin content analysis was conducted by referring to the AOAC method (2005). $\mathrm{NH}_{3}$ production was measured by Microdiffusion Conway Method (GLP, 1969), and VFA proportion was measured using gas chromatography (GC) (Supelco, 2015).

\section{Statistical Analysis}

Data were analyzed by using ANOVA by the SPSS 16 software program. DMRT was conducted if a significant difference was observed (Steel \& Torrie, 1997).

\section{RESULTS}

\section{Nutrient Contents of Whole Plant Sorghum-Mutant Lines}

There was no interaction between sorghum-mutant lines and generative stage at harvest time on nutrient content except on TDN. Patir 3.7 sorghum harvested at the hard-dough stage produced the highest TDN (59.98\%) (Table 1).

The sorghum-mutant line did not significantly affect DM, ash, and crude fat contents of whole plant sorghum. However, the sorghum-mutant line significantly affected $(p<0.05) \mathrm{CP}$ and crude-fiber contents of whole plant sorghum. Non BMR sorghum line (Patir 3.1) had 
the lowest crude protein contents $(8.54 \%)$ compared to Patir 3.2 (9.28\%) and Patir 3.7 (9.06\%).

The generative stage at harvest time significantly affected the DM, CF, ash, and crude fat contents of whole plant sorghum $(p<0.01)$. DM contents were significantly higher in whole plant sorghum harvested at the hard-dough stage compared to those harvested at the flowering stage and soft-dough stage $(p<0.01)$. The $\mathrm{CF}$ content of the whole plant sorghum harvested at the flowering stage was the highest $(27.47 \%)(p<0.01)$ and decreased $(p<0.01)$ in those harvested at the soft dough stage $(18.16 \%)$ and further decreased $(p<0.01)$ in those harvested at hard-dough stage (14.72\%). The ash content decreased in whole plant sorghum harvested at the hard-dough stage. The crude fat content of whole plant sorghum harvested at the advanced maturity stage and whole plant sorghum harvested at the hard-dough stage produced the highest crude fat content $(2.02 \%)$. The sorghum-mutant lines affected $\mathrm{CP}$ and CF contents of whole plant sorghum. BMR sorghum-mutant line produced a higher $\mathrm{CP}$ than the non-BMR line, but the decreased $C F$ trend is not found in the BMR line.

\section{Fiber Fraction Content of Whole Plant Sorghum Mutant Lines}

The contents of fiber fractions are presented in Table 2. There was no interaction between sorghum- mutant lines and generative stage at harvest time on fiber fraction content in this study. The ADF, NDF, lignin, and cellulose contents increased significantly $(p<0.01)$ with the increased generative stage at harvest time. On the other hand, ADF and lignin contents were also affected by sorghum-mutant lines $(p<0.05)$. However, NDF and cellulose contents were not affected by the sorghum-mutant line. In addition, the hemicellulose content was not affected by both sorghum-mutant lines and harvest time.

\section{Calcium (Ca) and Phosphorus (P) Contents of Whole Plant Sorghum Mutant Lines}

The contents of $\mathrm{Ca}$ and $\mathrm{P}$ in the whole plant sorghum-mutant lines were not affected by both of the sorghum-mutant lines and harvest time, and there was no interaction between them. The ranges of $\mathrm{Ca}$ and $\mathrm{P}$ contents were $0.24 \%-0.32 \%$ and $0.15 \%-0.20 \%$, respectively (Table 3).

\section{Tannin Content in Panicle}

The tannin content was analyzed in panicles (Table 4). The sorghum-mutant line did not affect the tannin content in the panicle. However, the generative stage at harvest time significantly affected the tannin content in the panicle $(p<0.05)$. In addition, there was a highly sig-

Table 1. Nutrient content of whole plant sorghum-mutant lines (\% dry matter basis)

\begin{tabular}{|c|c|c|c|c|c|}
\hline \multirow{2}{*}{ Nutrients } & \multirow{2}{*}{$\begin{array}{l}\text { Sorghum-mutant } \\
\text { lines }\end{array}$} & \multicolumn{3}{|c|}{ Harvest times } & \multirow{2}{*}{ Mean } \\
\hline & & Flowering & Soft dough & Hard dough & \\
\hline \multirow[t]{4}{*}{ Dry matter } & Patir 3.1 & $27.42 \pm 1.16$ & $28.20 \pm 0.41$ & $56.82 \pm 1.51$ & $37.48 \pm 14.54$ \\
\hline & Patir 3.2 & $26.77 \pm 0.46$ & $28.70 \pm 0.91$ & $56.31 \pm 4.05$ & $37.26 \pm 14.46$ \\
\hline & Patir 3.7 & $28.69 \pm 3.10$ & $29.06 \pm 4.78$ & $55.50 \pm 3.72$ & $37.75 \pm 13.74$ \\
\hline & Mean & $27.63 \pm 1.88^{\text {В }}$ & $28.65 \pm 2.47^{\mathrm{B}}$ & $56.21 \pm 2.91^{\mathrm{A}}$ & \\
\hline \multirow[t]{4}{*}{ Crude protein } & Patir 3.1 & $9.20 \pm 0.37$ & $8.54 \pm 0.58$ & $7.89 \pm 0.26$ & $8.54 \pm 0.41^{b}$ \\
\hline & Patir 3.2 & $9.38 \pm 0.81$ & $9.34 \pm 0.21$ & $9.12 \pm 0.40$ & $9.28 \pm 0.47^{a}$ \\
\hline & Patir 3.7 & $8.79 \pm 0.31$ & $9.04 \pm 0.56$ & $9.36 \pm 0.46$ & $9.06 \pm 0.45^{\mathrm{a}}$ \\
\hline & Mean & $9.12 \pm 0.50$ & $8.97 \pm 0.45$ & $8.79 \pm 0.37$ & \\
\hline \multirow[t]{4}{*}{ Crude fiber } & Patir 3.1 & $26.01 \pm 1.15$ & $18.00 \pm 0.46$ & $14.56 \pm 0.41$ & $19.52 \pm 0.67^{b}$ \\
\hline & Patir 3.2 & $28.51 \pm 1.57$ & $19.66 \pm 0.93$ & $15.52 \pm 1.50$ & $21.23 \pm 1.33^{a}$ \\
\hline & Patir 3.7 & $27.88 \pm 2.43$ & $16.80 \pm 2.00$ & $14.08 \pm 0.73$ & $19.59 \pm 1.72^{\mathrm{b}}$ \\
\hline & Mean & $27.47 \pm 1.72^{\mathrm{A}}$ & $18.16 \pm 1.13^{\text {В }}$ & $14.72 \pm 0.88^{\mathrm{C}}$ & \\
\hline \multirow[t]{4}{*}{ Ash } & Patir 3.1 & $7.05 \pm 0.50$ & $6.62 \pm 0.51$ & $6.66 \pm 0.13$ & $6.78 \pm 0.38$ \\
\hline & Patir 3.2 & $6.96 \pm 0.56$ & $6.37 \pm 0.32$ & $6.02 \pm 0.48$ & $6.66 \pm 0.45$ \\
\hline & Patir 3.7 & $6.70 \pm 0.21$ & $6.89 \pm 0.22$ & $5.93 \pm 0.36$ & $6.50 \pm 0.26$ \\
\hline & Mean & $6.90 \pm 0.42^{\mathrm{A}}$ & $6.63 \pm 0.35^{\mathrm{A}}$ & $6.20 \pm 0.32^{\mathrm{B}}$ & \\
\hline \multirow[t]{4}{*}{ Ether extract } & Patir 3.1 & $1.39 \pm 0.36$ & $1.36 \pm 0.19$ & $1.95 \pm 0.03$ & $1.57 \pm 0.19$ \\
\hline & Patir 3.2 & $1.16 \pm 0.27$ & $1.86 \pm 0.34$ & $1.83 \pm 0.34$ & $1.61 \pm 0.32$ \\
\hline & Patir 3.7 & $1.20 \pm 0.26$ & $1.80 \pm 0.32$ & $2.27 \pm 0.09$ & $1.75 \pm 0.23$ \\
\hline & Mean & $1.25 \pm 0.30^{\mathrm{C}}$ & $1.67 \pm 0.28^{\mathrm{B}}$ & $2.02 \pm 0.15^{\mathrm{A}}$ & \\
\hline \multirow{4}{*}{$\begin{array}{l}\text { Total digestible nu- } \\
\text { trients (TDN) }\end{array}$} & Patir 3.1 & $50.55 \pm 0.11^{\mathrm{e}}$ & $54.73 \pm 0.15^{\mathrm{d}}$ & $57.73 \pm 0.50^{\mathrm{b}}$ & $54.34 \pm 0.25^{\mathrm{B}}$ \\
\hline & Patir 3.2 & $49.71 \pm 0.64^{\mathrm{e}}$ & $54.87 \pm 0.59^{\mathrm{d}}$ & $57.81 \pm 1.20^{\mathrm{b}}$ & $54.13 \pm 0.81^{\mathrm{B}}$ \\
\hline & Patir 3.7 & $49.83 \pm 0.84^{\mathrm{e}}$ & $56.18 \pm 1.00^{c}$ & $59.98 \pm 0.82^{\mathrm{a}}$ & $55.33 \pm 0.89^{\mathrm{A}}$ \\
\hline & Mean & $50.03 \pm 0.53$ & $55.26 \pm 0.58$ & $58.51 \pm 0.84$ & \\
\hline
\end{tabular}

Note: Means in the same line and column in the same variable with different upper case superscripts differ highly significantly (p<0.01). Means in the same line column in the same variable with different lower case superscripts differ significantly $(\mathrm{p}<0.05)$. ns= nonsignificant; Patir $3.1=$ non BMR sorghum-mutant line; Patir 3.2-Patir 3.7= BMR sorghum-mutant lines. 
Table 2. Fiber fraction content of whole plant sorghum-mutant lines (\%)

\begin{tabular}{|c|c|c|c|c|c|}
\hline \multirow{2}{*}{ Fiber fraction } & \multirow{2}{*}{$\begin{array}{l}\text { Sorghum-mutant } \\
\text { lines }\end{array}$} & \multicolumn{3}{|c|}{ Harvest times } & \multirow{2}{*}{ Mean } \\
\hline & & Flowering & Soft dough & Hard dough & \\
\hline \multirow[t]{4}{*}{$\mathrm{ADF}$} & Patir 3.1 & $48.00 \pm 3.26$ & $36.08 \pm 1.43$ & $29.08 \pm 1.60$ & $37.72 \pm 2.10^{\mathrm{a}}$ \\
\hline & Patir 3.2 & $47.51 \pm 3.68$ & $32.46 \pm 1.21$ & $27.04 \pm 0.55$ & $35.67 \pm 1.81^{\mathrm{b}}$ \\
\hline & Patir 3.7 & $46.10 \pm 3.04$ & $30.86 \pm 0.99$ & $27.17 \pm 0.45$ & $34.71 \pm 1.49^{b}$ \\
\hline & Mean & $47.20 \pm 3.33^{\mathrm{A}}$ & $33.13 \pm 1.21^{\mathrm{B}}$ & $27.77 \pm 0.87^{C}$ & \\
\hline \multirow[t]{4}{*}{ NDF } & Patir 3.1 & $69.69 \pm 1.30$ & $56.24 \pm 4.79$ & $53.67 \pm 1.95$ & $59.87 \pm 2.68$ \\
\hline & Patir 3.2 & $69.25 \pm 3.65$ & $56.34 \pm 1.85$ & $50.75 \pm 1.78$ & $58.78 \pm 2.43$ \\
\hline & Patir 3.7 & $69.03 \pm 2.63$ & $52.34 \pm 0.94$ & $48.07 \pm 4.74$ & $56.48 \pm 2.77$ \\
\hline & Mean & $69.32 \pm 2.53^{\mathrm{A}}$ & $54.97 \pm 2.52^{\text {B }}$ & $50.83 \pm 2.82^{C}$ & \\
\hline \multirow[t]{4}{*}{ Lignin } & Patir 3.1 & $9.65 \pm 1.92$ & $8.11 \pm 0.20$ & $7.19 \pm 1.24$ & $8.32 \pm 1.12 a$ \\
\hline & Patir 3.2 & $8.38 \pm 2.01$ & $5.75 \pm 0.90$ & $6.33 \pm 0.43$ & $6.82 \pm 1.11 \mathrm{~b}$ \\
\hline & Patir 3.7 & $7.88 \pm 1.57$ & $5.75 \pm 0.83$ & $6.72 \pm 0.86$ & $6.78 \pm 1.08 \mathrm{~b}$ \\
\hline & Mean & $8.63 \pm 1.83^{\mathrm{A}}$ & $6.54 \pm 0.64^{\mathrm{B}}$ & $6.75 \pm 0.84^{\text {B }}$ & \\
\hline \multirow[t]{4}{*}{ Cellulose } & Patir 3.1 & $36.55 \pm 1.69$ & $26.13 \pm 1.26$ & $19.89 \pm 1.54$ & $27.53 \pm 1.50$ \\
\hline & Patir 3.2 & $37.38 \pm 1.07$ & $24.68 \pm 0.39$ & $17.36 \pm 0.50$ & $26.47 \pm 0.65$ \\
\hline & Patir 3.7 & $36.49 \pm 1.91$ & $23.88 \pm 1.07$ & $17.86 \pm 0.82$ & $26.07 \pm 1.27$ \\
\hline & Mean & $36.81 \pm 1.56^{\mathrm{A}}$ & $24.89 \pm 0.91^{\text {B }}$ & $18.37 \pm 0.95^{C}$ & \\
\hline \multirow[t]{4}{*}{ Hemicellulose } & Patir 3.1 & $21.68 \pm 3.90$ & $20.16 \pm 3.71$ & $24.58 \pm 1.99$ & $22.14 \pm 3.47$ \\
\hline & Patir 3.2 & $21.74 \pm 3.50$ & $22.88 \pm 2.42$ & $23.71 \pm 1.23$ & $23.11 \pm 2.44$ \\
\hline & Patir 3.7 & $22.93 \pm 1.43$ & $21.48 \pm 0.05$ & $20.89 \pm 4.55$ & $21.76 \pm 2.55$ \\
\hline & Mean & $22.12 \pm 2.78$ & $21.84 \pm 2.75$ & $23.06 \pm 3.05$ & \\
\hline
\end{tabular}

Note: Means in the same line and column in the same parameter with different upper case superscripts differ highly significantly (p<0.01). Means in the same line and column with different lower case superscripts differ significantly $(\mathrm{p}<0.05)$. ns= nonsignificant; Patir 3.1=non BMR sorghum-mutant line; Patir 3.2-Patir 3.7= BMR sorghum-mutant lines; $\mathrm{ADF}=$ acid detergent fiber; $\mathrm{NDF}=$ neutral detergent fiber.

Table 3. Calcium and phosphorus content of whole plant sorghum-mutant lines (\%)

\begin{tabular}{cccccc}
\hline \multirow{2}{*}{ Mineral } & Sorghum-mutant & \multicolumn{3}{c}{ Harvest times } & \multirow{2}{*}{ Mean } \\
\cline { 3 - 4 } & lines & Flowering & Soft dough & Hard dough & $0.23 \pm 0.09$ \\
& Patir 3.1 & $0.26 \pm 0.09$ & $0.23 \pm 0.09$ & $0.21 \pm 0.09$ & $0.23 \pm 0.05$ \\
& Patir 3.2 & $0.23 \pm 0.05$ & $0.25 \pm 0.08$ & $0.21 \pm 0.02$ & $0.24 \pm 0.07$ \\
& Patir 3.7 & $0.14 \pm 0.01$ & $0.24 \pm 0.03$ & $0.32 \pm 0.16$ & $0.16 \pm 0.02$ \\
Pean & $0.21 \pm 0.05$ & $0.24 \pm 0.07$ & $0.25 \pm 0.09$ & $0.18 \pm 0.01$ \\
& Patir 3.1 & $0.17 \pm 0.01$ & $0.17 \pm 0.03$ & $0.15 \pm 0.01$ & $0.18 \pm 0.03$ \\
\end{tabular}

nificant interaction effect $(\mathrm{p}<0.01)$ between the sorghum lines and the generative stage at harvest time for panicle tannins. The highest tannin content was produced in the combination treatment of the Patir 3.1 at the soft-dough stage $(1.04 \%)$, while the lowest was the combination of Patir 3.1 at the flowering stage $(0.12 \%)$. The advanced maturity of the plant affected the tannin content of panicle in this study. The BMR line produced a lower tannin content than non-BMR line.

\section{In Vitro Fiber Fraction Digestibility}

Based on Table 5, sorghum-mutant lines significantly affected ADFD in vitro $(\mathrm{p}<0.01)$, but harvest time had no effect on ADFD ( $>>0.05)$, and there was no interaction between the two factors. The ADF digestibility of Patir $3.1(48.68 \%)$ was lower than Patir 3.2
(55.08\%) and Patir 3.7 (55.01\%). Meanwhile, the NDFD was significantly affected by both sorghum-mutant lines and generative stage at harvest time $(\mathrm{p}<0.01)$. However, there was no interaction effect between sorghum mutant line and generative stage at harvest time on NDFD. It was found that NDFDs were similar in Patir 3.1 (51.44\%) and in Patir 3.7 (53.60\%) but significantly lower than that in Patir 3.2 (57.24\%). In this study, the hard-dough phase produces the highest NDF digestibility (57.74\%) compared to the soft-dough phase $(53.17 \%)$ and flowering phase $(51.37 \%)$.

\section{In Vitro Rumen Fluid Characteristics and Ruminal Organic Acids Production}

Rumen characteristics, proportions of VFA, and A:P ratio in rumen liquid is presented in Table 6 and 
Table 4. Panicle tannin content of sorghum-mutant lines (\%)

\begin{tabular}{ccccc}
\hline \multirow{2}{*}{ Sorghum-mutant lines } & \multicolumn{3}{c}{ Harvest times } & \multirow{2}{*}{ Mean } \\
\cline { 2 - 4 } & Flowering & Soft dough & Hard dough & $0.53 \pm 0.03$ \\
Patir 3.1 & $0.12 \pm 0.08^{\mathrm{B}}$ & $1.04 \pm 0.07^{\mathrm{A}}$ & $0.42 \pm 0.03^{\mathrm{B}}$ & $0.58 \pm 0.07$ \\
Patir 3.2 & $0.77 \pm 0.12^{\mathrm{A}}$ & $0.59 \pm 0.15^{\mathrm{AB}}$ & $0.38 \pm 0.02^{\mathrm{B}}$ & $0.50 \pm 0.04$ \\
Patir 3.7 & $0.61 \pm 0.12^{\mathrm{A}}$ & $0.51 \pm 0.04^{\mathrm{AB}}$ & $0.37 \pm 0.06^{\mathrm{B}}$ & \\
Mean & $0.50 \pm 0.10^{\mathrm{AB}}$ & $0.71 \pm 0.09^{\mathrm{A}}$ & $0.39 \pm 0.04^{\mathrm{B}}$ & \\
\hline
\end{tabular}

Note: Means in the same row with different upper case superscripts differ highly significantly $(p<0.01)$. Patir $3.1=$ non BMR sorghum-mutant line; Patir 3.2-Patir 3.7= BMR sorghum-mutant lines.

Table 5. Fiber fraction digestibility of sorghum-mutant lines (\%)

\begin{tabular}{cccccc}
\hline \multirow{2}{*}{ Variables } & Maturity stages & \multicolumn{3}{c}{ Sorghum-mutant lines } & \multirow{2}{*}{ Mean } \\
\cline { 3 - 5 } & & Patir 3.1 & Patir 3.2 & Patir 3.7 & $51.48 \pm 2.74$ \\
\cline { 3 - 5 } ADFD & Flowering & $46.70 \pm 2.23$ & $54.03 \pm 2.16$ & $53.73 \pm 3.82$ & $53.38 \pm 3.20$ \\
& Soft dough & $49.21 \pm 3.61$ & $55.11 \pm 3.01$ & $55.83 \pm 2.99$ & $53.90 \pm 2.27$ \\
& Hard dough & $50.14 \pm 3.39$ & $56.09 \pm 3.12$ & $55.47 \pm 0.29$ & $51.37 \pm 2.97^{\mathrm{B}}$ \\
& Mean & $48.68 \pm 3.08^{\mathrm{B}}$ & $55.08 \pm 2.76^{\mathrm{A}}$ & $55.01 \pm 2.37^{\mathrm{A}}$ & $53.17 \pm 3.97^{\mathrm{B}}$ \\
& Flowering & $49.93 \pm 2.73$ & $51.62 \pm 2.26$ & $52.57 \pm 3.91$ & $57.74 \pm 2.36^{\mathrm{A}}$ \\
& Soft dough & $48.79 \pm 3.71$ & $58.22 \pm 3.79$ & $52.49 \pm 4.40$ & $55.75 \pm 1.16$ \\
& Hard dough & $55.59 \pm 3.49$ & $61.89 \pm 2.42$ & $53.60 \pm 3.16^{\mathrm{B}}$ & \\
\hline
\end{tabular}

Note: Means in the same line and column in the same parameter with different upper case superscripts differ highly significantly ( $<<0.01)$. Means in the same line and column in the same parameter with different lower case superscripts differ significantly $(\mathrm{p}<0.05)$. Patir $3.1=$ non BMR sorghum-mutant line; Patir 3.2-Patir 3.7= BMR sorghum-mutant lines; $\mathrm{ADFD}=$ acid detergent fiber digestibility; NDFD= neutral detergent fiber digestibility.

Table 6. Rumen characteristics ( $\mathrm{pH}, \mathrm{NH}_{3}$, and VFA) of brown-midrib sorghum mutant lines at different maturity stages in vitro

\begin{tabular}{|c|c|c|c|c|c|}
\hline \multirow{2}{*}{ Variables } & \multirow{2}{*}{ Harvest times } & \multicolumn{3}{|c|}{ Sorghum-mutant lines } & \multirow{2}{*}{ Mean } \\
\hline & & Patir 3.1 & Patir 3.2 & Patir 3.7 & \\
\hline \multirow[t]{4}{*}{$\mathrm{pH}$} & Flowering & $6.70 \pm 0.10$ & $6.70 \pm 0.10$ & $6.70 \pm 0.00$ & $6.70 \pm 0.07$ \\
\hline & Soft dough & $6.70 \pm 0.00$ & $6.63 \pm 0.00$ & $6.67 \pm 0.06$ & $6.67 \pm 0.04$ \\
\hline & Hard dough & $6.70 \pm 0.10$ & $6.70 \pm 0.00$ & $6.73 \pm 0.06$ & $6.71 \pm 0.05$ \\
\hline & Mean & $6.70 \pm 0.07$ & $6.68 \pm 0.05$ & $6.70 \pm 0.04$ & \\
\hline \multirow[t]{4}{*}{$\mathrm{NH}_{3}(\mathrm{mM})$} & Flowering & $10.67 \pm 0.14$ & $10.12 \pm 2.10$ & $10.20 \pm 2.77$ & $10.33 \pm 1.67^{\mathrm{A}}$ \\
\hline & Soft dough & $7.89 \pm 1.63$ & $5.81 \pm 0.77$ & $5.11 \pm 0.37$ & $6.27 \pm 0.92^{\mathrm{C}}$ \\
\hline & Hard dough & $9.94 \pm 1.21$ & $9.04 \pm 1.19$ & $7.33 \pm 0.75$ & $8.77 \pm 1.05^{\mathrm{B}}$ \\
\hline & Mean & $9.50 \pm 0.99^{\mathrm{A}}$ & $8.32 \pm 0.99^{\mathrm{AB}}$ & $7.55 \pm 1.30^{\mathrm{B}}$ & \\
\hline \multirow[t]{4}{*}{ VFA (mM) } & Flowering & $132.60 \pm 11.94^{\mathrm{A}}$ & $116.78 \pm 11.00^{\mathrm{B}}$ & $117.51 \pm 17.80^{\mathrm{B}}$ & $122.30 \pm 13.58$ \\
\hline & Soft dough & $90.34 \pm 9.56^{\mathrm{C}}$ & $75.48 \pm 14.79^{\mathrm{D}}$ & $73.45 \pm 3.04^{\mathrm{D}}$ & $79.76 \pm 9.13$ \\
\hline & Hard dough & $127.52 \pm 11.10^{\mathrm{AB}}$ & $101.12 \pm 11.55^{\mathrm{C}}$ & $73.34 \pm 7.14^{\mathrm{D}}$ & $100.66 \pm 9.93$ \\
\hline & Mean & $116.82 \pm 10.87$ & $97.79 \pm 10.87$ & $88.10 \pm 9.33$ & \\
\hline
\end{tabular}

Note: Means in the same line and column in the same parameter with different upper case superscripts differ highly significantly ( $<<0.01)$. Means in the same line and column in the same parameter with different lower case superscripts differ significantly $(\mathrm{p}<0.05)$. Patir 3.1= non BMR sorghum-mutant line; Patir 3.2-Patir 3.7= BMR sorghum-mutant lines; $\mathrm{ADFD}=$ acid detergent fiber digestibility; NDFD= neutral detergent fiber digestibility.

Table 7. The $\mathrm{pH}$ ranges were neutral in all treatments in this study, and there was no effect of sorghummutant line and generative stage on the $\mathrm{pH}$ of rumen fluid. The sorghum-mutant line and generative stage at harvest significantly affected the $\mathrm{NH}_{3}$ concentration in the rumen fluid. However, there was no interaction between the sorghum mutant line and the generative stage on the $\mathrm{NH}_{3}$ concentration in the rumen fluid. The sorghum-mutant line had a lower $\mathrm{NH}_{3}$ concentration in the rumen fluid compared to the non-mutant line $(p<0.05)$. Sorghum harvest at the flowering stage had the highest $\mathrm{NH}_{3}$ concentrations in the rumen fluid $(\mathrm{p}<0.05)$ compared to those harvested at soft- and hard-doughs stages. There was an interaction effect of sorghummutant lines and maturity stage at harvest on the in vitro rumen fluid VFA production. Patir 3.1 harvested at the flowering stage produced a high VFA production of $132.60 \mathrm{mM}$.

The concentrations of acetate, propionate, and isobutyrate in rumen fluid were not affected by either sorghum-mutant lines or the maturity stage $(p>0.05)$. Even though there was a decrease in NDF content in the 
Table 7. VFA proportions and ratios of acetate to propionate in sorghum-mutant lines at different maturity stages

\begin{tabular}{|c|c|c|c|c|c|}
\hline \multirow{2}{*}{$\begin{array}{l}\text { Ruminal organic } \\
\text { acids (mM) }\end{array}$} & \multirow{2}{*}{ Maturity stages } & \multicolumn{3}{|c|}{ Sorghum-mutant lines } & \multirow{2}{*}{ Mean } \\
\hline & & Patir 3.1 & Patir 3.2 & Patir 3.7 & \\
\hline \multirow[t]{4}{*}{ Acetate } & Flowering & $32.92 \pm 2.45$ & $30.45 \pm 4.46$ & $29.21 \pm 2.11$ & $30.86 \pm 3.01$ \\
\hline & Soft dough & $30.20 \pm 5.80$ & $30.12 \pm 5.01$ & $29.05 \pm 2.23$ & $29.79 \pm 4.35$ \\
\hline & Hard dough & $29.94 \pm 3.60$ & $28.93 \pm 3.42$ & $28.79 \pm 0.66$ & $29.22 \pm 2.56$ \\
\hline & Mean & $31.02 \pm 3.95$ & $29.84 \pm 4.30$ & $29.02 \pm 1.67$ & \\
\hline \multirow[t]{4}{*}{ Propionate } & Flowering & $9.56 \pm 0.92$ & $10.44 \pm 2.71$ & $9.92 \pm 3.26$ & $9.97 \pm 2.30$ \\
\hline & Soft dough & $9.39 \pm 0.72$ & $11.94 \pm 1.64$ & $10.92 \pm 3.03$ & $10.75 \pm 1.79$ \\
\hline & Hard dough & $10.37 \pm 2.27$ & $11.36 \pm 3.29$ & $11.07 \pm 1.26$ & $10.93 \pm 2.27$ \\
\hline & Mean & $9.77 \pm 1.30$ & $11.25 \pm 2.55$ & $10.64 \pm 2.51$ & \\
\hline \multirow[t]{4}{*}{ Isobutyrate } & Flowering & $1.84 \pm 0.43$ & $1.49 \pm 0.39$ & $1.11 \pm 0.39$ & $1.48 \pm 0.40$ \\
\hline & Soft dough & $1.26 \pm 0.41$ & $1.23 \pm 0.41$ & $0.97 \pm 0.40$ & $1.15 \pm 0.41$ \\
\hline & Hard dough & $1.20 \pm 0.69$ & $1.15 \pm 0.08$ & $0.88 \pm 0.36$ & $1.08 \pm 0.38$ \\
\hline & Mean & $1.43 \pm 0.51$ & $1.29 \pm 0.29$ & $0.99 \pm 0.38$ & \\
\hline \multirow[t]{4}{*}{ Butyrate } & Flowering & $4.37 \pm 0.57$ & $3.37 \pm 0.13$ & $2.67 \pm 1.28$ & $3.47 \pm 0.66$ \\
\hline & Soft dough & $3.73 \pm 1.03$ & $2.75 \pm 0.55$ & $1.58 \pm 0.69$ & $2.69 \pm 0.76$ \\
\hline & Hard dough & $2.34 \pm 1.40$ & $2.58 \pm 0.75$ & $2.44 \pm 1.13$ & $2.45 \pm 1.09$ \\
\hline & Mean & $3.48 \pm 1.00^{\mathrm{a}}$ & $2.90 \pm 0.48^{\mathrm{ab}}$ & $2.23 \pm 1.04^{b}$ & \\
\hline \multirow[t]{4}{*}{ Isovalerate } & Flowering & $1.55 \pm 0.28$ & $1.43 \pm 0.03$ & $0.83 \pm 0.40$ & $1.27 \pm 0.24^{\mathrm{a}}$ \\
\hline & Soft dough & $1.02 \pm 0.45$ & $0.88 \pm 0.71$ & $0.85 \pm 0.41$ & $0.91 \pm 0.52^{b}$ \\
\hline & Hard dough & $1.17 \pm 0.60$ & $1.01 \pm 0.16$ & $0.73 \pm 0.33$ & $0.97 \pm 0.36^{b}$ \\
\hline & Mean & $1.25 \pm 0.44^{\mathrm{a}}$ & $1.10 \pm 0.30^{\mathrm{a}}$ & $0.80 \pm 0.38^{b}$ & \\
\hline \multirow[t]{4}{*}{ Valerate } & Flowering & $1.35 \pm 0.18$ & $1.30 \pm 0.16$ & $0.57 \pm 0.36$ & $1.07 \pm 0.23^{A}$ \\
\hline & Soft dough & $0.66 \pm 0.40$ & $0.71 \pm 0.36$ & $0.70 \pm 0.66$ & $0.69 \pm 0.47^{\mathrm{B}}$ \\
\hline & Hard dough & $0.69 \pm 0.38$ & $0.75 \pm 0.29$ & $0.51 \pm 0.35$ & $0.65 \pm 0.34^{\mathrm{B}}$ \\
\hline & Mean & $0.90 \pm 0.32^{\mathrm{ab}}$ & $0.92 \pm 0.27^{a}$ & $0.59 \pm 0.46^{\mathrm{b}}$ & \\
\hline \multirow[t]{4}{*}{$\mathrm{A}: \mathrm{P}$} & Flowering & $3.59 \pm 0.13$ & $3.02 \pm 0.65$ & $3.10 \pm 0.70$ & $3.24 \pm 0.49$ \\
\hline & Soft dough & $3.20 \pm 0.37$ & $2.59 \pm 0.75$ & $2.82 \pm 0.92$ & $2.87 \pm 0.68$ \\
\hline & Hard dough & $3.02 \pm 0.93$ & $2.70 \pm 0.80$ & $2.63 \pm 0.36$ & $2.78 \pm 0.70$ \\
\hline & Mean & $3.27 \pm 0.48$ & $2.77 \pm 0.73$ & $2.85 \pm 0.66$ & \\
\hline
\end{tabular}

Note: Means in the same line and column in the same parameter with different upper case superscripts differ highly significantly ( $p<0.01)$. Means in the same line and column in the same parameter with different lowercase superscripts differ significantly $(p<0.05)$. ns= nonsignificant; Patir 3.1= non BMR sorghum-mutant line; Patir 3.2-Patir 3.7= BMR sorghum-mutant lines.

BMR sorghum-mutant lines (Patir 3.2 and Patir 3.7), it did not cause a significant decrease in acetic acid in the rumen fluid. The proportion of butyrate, isovalerate, and valerate were influenced by sorghum-mutant lines $(\mathrm{p}<0.05)$, but the harvest times affected the proportion of both isovalerate $(p<0.05)$ and valerate $(p<0.01)$. The generative stage at harvest did not affect the proportion of butyrate. There were no significant interaction effects of sorghum-mutant line and generative stage at harvest on the proportions of butyrate, isovalerate, and valerate. The proportions of butyrate, isovalerate, and valerate were the lowest in the sorghum-mutant line Patir 3.7. In addition, valerate and isovalerate proportions decreased with the increased generative stage of sorghum at harvest.

\section{DISCUSSION}

The increase of DM content was affected by the maturity stage and plant age. We found that the harvest time at the hard-dough stage produced a high DM content. This high DM content was related to the longer photosynthesize that was the seed-filling stage period of the plant. At the hard-dough stage, the plant age was 110 DAS, so that photosynthesis activity was longer than both at the flowering (74 DAS) and soft-dough stages (90 DAS). This result was in line with Koca \& Erekul (2016) report, stating that DM accumulation would increase from emergence to maturity and at the fruiting stage.

The CP content was higher on BMR sorghum-mutant lines compared to non-BMR sorghum, and genetic factors influenced this difference. This result is in line with the result reported by Nohong \& Islamiyati (2018) that the $\mathrm{CP}$ of $\mathrm{BMR}$ sorghum is higher than that of Samurai-2 variety (non-BMR sorghum mutant). Aguilar et al. (2014) state that the BMR has a higher protein content compared to the normal non-mutant sorghum.

On late maturity, CF was affected by grain filling. The stage from the soft-dough stage to the hard-dough stage is the grain filling stage to produce kernel. Sorghum grain consists of non-structural carbohydrates such as starch, and on the other hand, sugar accumulation in the stem increases with the increasing time 
until harvesting. Sriagtula et al. (2017) mention that the decreased CF content in stems is caused by the lower proportion of structural carbohydrate as sugar accumulated in the stems and carbohydrate is translocated for grain development.

The ash content in the whole sorghum plant decreases with the increasing maturity stage at harvest time. At the hard-dough stage, the ash content decreased significantly $(p<0.01)$, and this result is in line with the result reported by Xie et al. (2012). Sriagtula et al. (2017) and Rosser (2013) state that at the hard-dough phase, the proportion of panicles are dominant in the total plants, and panicles are rich in starch which will affect the percentage of ash.

The crude-fat content increased with the increasing maturity stage of sorghum at harvest due to the increased starch content during the grain-filling process. Consistent with our earlier studies, at the hard-dough stage, the proportion of panicles (grain) reach $60 \%$ (Sriagtula et al., 2016), so that the starch content is the highest in this phase, as well as the crude-fat content. Refers to Wang et al. (2018), lipids are part of the starch in the form of free fatty acids (FFA).

There was an interaction effect between the sorghum-mutant lines and the harvest time on TDN content. The results showed that Patir 3.7 harvested at the hard-dough phase produced the highest TDN content $(59.98 \%)$. The highest TDN content is related to increased nutrient content, especially $\mathrm{CP}$, and the decrease of fiber fraction, especially ADF, NDF, and lignin, which occurred at the hard-dough stage. At the hard-dough stage, the nitrogen-free extract (NFE) content increased, and this fact was supported by our earlier study, which found that the increasing starch content was related to the maturation of seeds and stem sugar contents at the hard-dough stage (Sriagtula et al., 2017). This study's results were in line with the report of Nair et al. (2018), which stated that at the advanced maturity, ADF, NDF, and lignin contents of forage barley decreased, whereas starch and TDN contents increased. TDN is calculated based on nutrient composition and digestibility. The higher starch but lower ADF and NDF contents can result in a high digestibility so it will increase the TDN content. These results were similar to the result reported by Nair et al. (2018) that TDN concentration of barley forage increased during the hard-dough stage.

The low ADF contents in the BMR sorghum-mutant lines are due to the low lignin content that is consistent with the literature that lignin is part of the ADF (Salama \& Nawar, 2016). Low lignin content in BMR sorghum-mutant lines is influenced by genetic factors, and BMR genes in plants cause a low lignin content and increase digestibility. A possible explanation for this result might be the lower activities of Cynnamyl Alcohol Dehydrogenase (CAD) and Cafeid Acid/5-hydroxyferulic acid O-methyltransferase (COMT) enzymes to play a role in lignin biosynthesis (Li et al., 2015).

The contents of ADF, NDF, lignin, and cellulose decreased with late harvest time, and these decreases were caused by the increased NFE contents at this phase. These results match to our observation in an earlier study that NFE content in BMR sorghum lines increases both in sugar on the stem and starch in the grain (panicle) during this phase (Sriagtula et al., 2017). Sriagtula et al. (2016b) state that there is a competition in using carbohydrate for the synthesis of sugar in the stem and starch in the panicles and for the fiber synthesis in the advanced maturity stage that eventually decrease the content of fiber fraction.

The $\mathrm{Ca}$ and $\mathrm{P}$ contents were not significant in sorghum whole plant in all harvest times, caused by the dynamics of mineral nutrition in the part of sorghum plants. During the vegetative stage, $\mathrm{Ca}$ and $\mathrm{P}$ were used for stem and leaf growths, and further during the grain filling period, $\mathrm{Ca}$ and $\mathrm{P}$ will be translocated to the generative parts of the plants (seeds) during the soft-dough and hard-dough stages. At the same phase, Ca dan P contents in both parts of the plant (stem and leaf) decreased, different from the panicle, where Ca dan P contents increased. This fact causes $\mathrm{Ca}$ and $\mathrm{P}$ contents in the whole plant of sorghum-mutant lines were not different. Gracia \& Grusak (2015) state that micronutrient in cereal is remobilized from flag leaves to the developing grain.

Tannin is an antinutrient compound that can inhibit the digestion of protein and starch. In sorghum plants, the content of tannins is abundant in seeds and in leaves (de Alameda et al., 2014; Hayes et al., 2016). The tannin content in the panicle increased at the soft-dough stage and decreased at the hard-dough stage. This result is in line with the result reported by Kaplan et al. (2014) that the tannin content of Sanguisorba-minor hay varied with maturity and decreased with the increasing maturity. The results showed that the dynamics of tannins in the panicle were different between BMR sorghummutant line and non-BMR at harvest time. The tannin content was affected by the interaction between the sorghum-mutant line and harvest time. The lowest tannin content was found in Patir 3.1 at the flowering stage, and the highest tannin content was found in Patir 3.1 at the soft-dough stage. Opposite to Patir 3.2 and Patir 3.7, the highest tannin content was found at the flowering stage and decreased to the soft-dough and hard-dough stages.

The tannin contents in the study ranged from $0.12 \%$ to $1.04 \%$. Sorghum-mutant lines have no high tannins. According to Pan et al. (2016), the whole sorghum plant was high in tannins if the content of tannin ranges from $1.11 \%-1.51 \%$. In this study, many bird attacks occurred on panicles (grain), which indicated that the sorghummutant lines have a low tannin content. This finding is consistent with the study of $\mathrm{Wu}$ et al. (2012), reporting that the higher tannin level in the panicle produced the lower seed damages caused by bird attacks. On the other hand, white grain sorghum showed a low tannin content. Cheng et al. (2009) and Sedghi et al. (2012) state that the high tannin content is the characteristic pigmentation on the seed coat (testa).

Assessment of NDFD and ADFD is important to quantify the nutritional value of the forage, and these components were strongly negatively correlated with both DMD and OMD (Lee, 2018). The BMR sorghummutant lines produced a higher ADF digestibility than the non-BMR sorghum because of ADF content in Patir $3.1(37 \%)$ was higher than those in Patir 3.2 (35\%) and 
Patir 3.7 (34\%) (Table 2). ADF content was described as a part of the undigestible matter on forage (Dasci \& Çomakli, 2011). Both sorghum-mutant lines and maturity stages at harvest affected the in vitro NDFD significantly $(p<0.01)$ without interaction effect.

The ADFD was found higher in BMR line than in the non-BMR line. One interesting finding is that the highest NDFD is found only in Patir 3.2 (57.24\%). This result is linear with the results of our earlier study that DMD and OMD in Patir 3.2 were 65\% and 66\%, respectively, that were higher than in Patir 3.7 (63\% and 63\%, respectively) and Patir 3.1 (60\% and 60\%, respectively) (Sriagtula et al., 2017). This result may be explained by the result reported by Jančík et al. (2010) that in general, NDF is the best variable of DM degradation because NDF represents the total matrix of insoluble fiber.

The NDFDs of sorghum-mutant lines are affected by maturity stages. Advanced maturity at the harddough stage produced the highest NDFD (57.74\%) but decreased at flowering and soft-dough stages (51.37\% and $53.17 \%$, respectively). This result may be explained by the fact that NDF contents decrease with the increased maturity stages from the flowering stage $(69.32 \%)$ to a soft-dough stage $(54.97 \%)$ and harddough stage $(50.83 \%)$ (Table 2). Lignin content at the hard-dough stage was $6.75 \%$ that was lower than that at flowering stages (8.63\%) (Table 2), and this decrease contributed to the increased NDFD at the hard-dough stage. This result agrees with the report of Raffrenato et al. (2017) that lignin content was negatively correlated with NDFD.

The VFA proportion is an important factor for determining feed utilization by ruminants (Saunders, 2015). There was a significant interaction effect between sorghum-mutant line and harvest time on VFA production. Total VFA production was higher in the non-BMR sorghum compared to the BMR line. This difference was due to the higher butyrate production in the nonBMR line (Table 7). However, acetate and propionate were not significantly different between sorghum lines. Patir 3.1 at the flowering stage produced the highest VFA concentration, although ADF and NDF contents were also higher. It was the reason that the ADFD and NDFD in Patir 3.1 were the lowest in the same phase at the flowering stage (Table 2 and Table 5), compared to BMR sorghum-mutant lines. This finding is in line with the results of Wahyono et al. (2019) that $\mathrm{NH}_{3}$ and VFA productions in vitro were not significant, even though the $\mathrm{CP}, \mathrm{ADF}$, and NDF contents were different. This result is contradictive with that reported by Chaugool et al. (2013) that the characteristics of ruminal fermentation of sorghum cultivars were directly associated with the rumen degradability.

There is no interaction effect between sorghummutant linen and regenerative stage at harvest time on $\mathrm{pH}$ and $\mathrm{NH}_{3}$ production in vitro. In general, the concentrations of $\mathrm{NH}_{3}$ and VFA were not affected by $\mathrm{CP}$ and CF contents (Table 1). Due to the method used to evaluate fermentation was in vitro, there was no absorption and recycling of the products of fermentation as in the in vivo in actual rumen conditions (Firsoni et al., 2010; Kisworo et al., 2017). There was no significant interaction effect between the sorghum-mutant line and generative stage at harvest time on ruminal organic acids. The proportion of acetate, propionate, and iso-butyrate were not significantly different despite ADF and lignin contents decreased with the advance of maturity (Table 2). This result is contradictive with the report of Rahman et al. (2013) that high fiber material will produce a higher acetate and butyrate than propionate. The lower fiber content of forages produces a higher propionate so that the A:P ratio decreases during rumen fermentation.

In this study, the ranges of acetate, propionate, and butyrate proportions were 28.79-32.92 mM; 9.39-11.94 $\mathrm{mM}$; and 1.58-4.37 $\mathrm{mM}$, respectively. These results are lower than those reported by Saunders (2015), who found that the proportion of VFA in maize ration based on corn silage BMR as acetate, propionate, isobutane, butyrate, valerate, and isovalerate were $60.5 \mathrm{mM}, 21.8$ $\mathrm{mM}, 1.05 \mathrm{mM}, 12.3 \mathrm{mM}, 1.44 \mathrm{mM}$, and $1.44 \mathrm{mM}$, respectively. The lower proportion of VFA found in the present study was caused by the material tested as a single feed, not in the form of a mixed ratio.

The A:P ratio in the present study was not affected by the sorghum-mutant line and maturity stage. The decreasing the A:P ratios in the BMR sorghum-mutant lines compared to control non-BMR sorghum (Patir 3.1) were not statistically significant. This nonsignificant difference was related to the proportion of acetate and propionate in BMR and non-BMR sorghum-mutant lines in this study showed no significant difference. The ratio of A:P on the Patir 3.2 and Patir 3.7 BMR sorghum-mutant lines were 2.77 and 2.85, respectively. This result is in line with the report of Saunders (2015) that the ratio A:P in corn silage-based BMR ratio was $2.75 \mathrm{mM}$.

\section{CONCLUSION}

BMR sorghum-mutant lines (Patir 3.2 and Patir 3.7) produce higher $\mathrm{CP}$, fiber fraction digestibility, and lower ADF and lignin than non-BMR sorghum-mutant lines (Patir 3.1). The proportion of rumen organic acids (acetate and propionate) and A: P ratio was not different in both sorghum-mutant lines and regenerative stage at harvest times, except butyrate. The best NDFD was found in Patir 3.2 BMR sorghum-mutant line. Harvesting at the hard-dough stage produced the highest in vitro NDFD. All sorghum-mutant lines and harvest time produce the same levels of acetate and propionate.

\section{CONFLICT OF INTEREST}

Luki Abdullah serves as an editor of the Tropical Animal Science Journal, but has no role in the decision to publish this article. We certify that there is no conflict of interest with any financial organization regarding the material discussed in the manuscript.

\section{ACKNOWLEDGMENT}

We would like to express our gratitude to SEAMEO-BIOTROP Bogor for sorghum mutant lines seed and all facilities during the study. 


\section{REFERENCES}

AOAC. 2005. Official Methods of Analysis of AOAC International. $18^{\text {th }}$ ed. Assoc. Off. Anal. Chem., Arlington.

Beck, P., K. Poe, B. Stewart, P. Capps, \& H. Gray. 2013. Effect of brown midrib gene and maturity at harvest on forage yield and nutritive quality of Sudan grass. Japanese Society of Grassland Science, Grassland Science. 59:52-58. https://doi. org/10.1111/grs.12007

Chaugool, J., M. Kondo, S. Kasuga, H. Naito, M. Goto, \& H. Ehara. 2013. Nutritional evaluation and in vitro ruminal fermentation of Sorghum cultivars. J. Food. Agric. Environ. 2:345-351.

Cheng, S., Y. Sun, \& L. Halgreen L. 2009. The relationships of Sorghum kernel pericarp and testa characteristics with tannin content. Asian J. Crop Sci. 1:1-5. https://doi. org/10.3923/ajcs.2009.1.5

Christensen, C. S. L. \& S. K. Rasmussen. 2019. Low lignin mutants and reduction of lignin content in grasses for increased utilisation of lignocellulose. Agronomy. 9:1-21. https://doi.org/10.3390/agronomy9050256

Dahir, M., K. X. Zhu, X. N. Guo, W. Aboshora, \& W. Peng. 2015. Possibility to utilize sorghum flour in a modern bread making industry. J. Acad. Ind. Res. 4:128-135.

Dasci, M. \& B. Comakli. 2011. Effects of fertilization on forage yield and quality in ranges sites with different tophographic structure. Turkish J. Field Crop. 1:15-22.

de Aguilar, P. B., D. A. de-Asis Pires, B. C. B. Frota, J. A. S. Rodrigues, S. T. dos-Reis, \& V. R. R. Junior. 2014. Nutritional characteristics of BMR mutant and normal sorghum genotypes used for cutting and grazing. Acta Sci. 3:259-264. https://doi.org/10.4025/actascianimsci. v36i3.21284

de Almeida, T. T., S. D. V. F. da Rosa., J. A. Oliveira., A. d. S. Oliveira., A. A. da Silva, \& D. D. S. Pereira. 2014. Influence of tannin on sorghum seed germination. Afr. J. Food Sci. Technol. 5:136-142.

Firsoni. F., E. Conny, \& Lisanti. 2010. Uji kecernaan in-vitro dedak padi yang mengandung daun paitan (Tithonia diversifolia (HEMSL.) A. Gray) dan kelor (Moringa oleifera, Lamk). JITV. 3:182-187.

GLP. 1969. General Laboratory Procedures, Department of Dairy Science. Univ Wisconsin, Madison (US).

Gracia, C. B. \& M. A. Grusak. 2015. Mineral accumulation in vegetative and reproductive tissues during seed development in Medicago truncatula. Front. Plant Sci. 6:622. https:// doi.org/10.3389/fpls.2015.00622

Hartadi, H., S. Reksohadiprojo, \& A. D. Tillman. 2005. Tabel Komposisi Pakan untuk Indonesia. Gadjah Mada University Press, Yogyakarta.

Hayes, C. M., B. D. Weers., M. Thakran., G. Burow., Z. Xin., Y. Emendack., J. J. Burke., W. L. Rooney, \& J. E. Mullet. 2016. Discovery of a dhurrin QTL in Sorghum bicolor: colonization of dhurrin biosynthesis and novel staygreen QTL. Crop Sci. 56:104-112. https://doi.org/10.2135/ cropsci2015.06.0379

ICCSR (Indonesia Climate Change Sectoral Roadmap). 2020. Scientific Basis: Analysis and Projection of Temperature and Rainfall. https://www.bappenas.go.id [21 December 2020].

Jancik, F., V. Koukolova, \& P. Homolka. 2010. Ruminal degradability of dry matter and neutral detergent fibre of grasses. Czech. J. Anim. Sci. 9:359-371. https://doi. org/10.17221/211/2009-CJAS

Kaplan, M., A. Kamalak., A. A. Kasra, \& I. Guven. 2014. Effect of maturity stages on potential nutritive value, methane production and condensed tannin content of Sanguisorba minor hay. Kafkas Univ. Vet. Fak. Derg. 20:445-449. https:// doi.org/10.9775/kvfd.2013.10383
Kisworo, A. N., A. Agus, Kustantinah, \& B. Suwignyo. 2017. Physicochemical characteristics, in vitro fermentation indicators, gas production kinetics, and degradability of solid herbal waste as alternative feed source for ruminants. Med. Pet. 2:101-110. https://doi.org/10.5398/ medpet.2017.40.2.101

Koca, Y. O. \& O. Erekul. 2016. Changes of dry matter, biomass and relatives growth ratewith different phenological stages of corn. Agriculture and Agricultural Science Procedia. 10:67-75. https://doi.org/10.1016/j.aaspro.2016.09.015

Lee, M. A. 2018. A global comparison of the nutritive values of forage plants grown in contrasting environments. J. Plant Res. 131:641-654. https://doi.org/10.1007/s10265-018-1024-y

Li, Y., P. Mao, W. Zhang, X. Wang, Y. You, H. Zhao, L. Zhai, \& G. Liu. 2015. Dynamic expression of the nutritive values in forage sorghum populations associated with white, green and brown midrid genotypes. Field Crops Res. 184:112 122. https://doi.org/10.1016/j.fcr.2015.09.008

Mathur, S., A. V. Umakanth, A. V. Tonapi, R. Sharma, \& M. K. Sharma. 2017. Sweet sorghum as biofuel feedstock: Recent advances and available resources. Biotechnol. Biofuels. 10:1-19. https://doi.org/10.1186/s13068-017-0834-9

Nair, J., A.D., Beattie, D. Christensen., P. Yu., T. McAllister., D. Damiran., \& J. J. McKinnon. 2018. Effect of variety and stage of maturity at harvest on nutrient and neutral detergent fiber digestibility of forage barley grown in western Canada Jayakrishnan. Can. J. Anim. Sci. 98:299-310. https:// doi.org/10.1139/cjas-2017-0060

Nohong, B. \& R. Islamiyati. 2018. The effect of bio-slurry fertilization on growth, dry matter yield and quality of hybrid sudangrass and sorghum (Sorghum bicolor) Samurai-2 variety. Bulg. J. Agric. Sci. 24:592-598.

Pan, 1., P. Li, X. K. Ma, Y. T. Xu, Q. Y. Tian, L. Liu, D. F. Li, \& X. S. Piao. 2016. Tannin is a key factor in the determination and prediction of energy content in sorghum grains fed to growing pigs. J. Anim. Sci. 94:2879-2889. https://doi. org/10.2527/jas.2016-0457

Raffrenato, E., R. Fievisohn., K. W. Cotanch., R. J. Grant., L. E. Chase, \& M. E. V. Amburgh. 2017. Effect of lignin linkages with other plant cell wall components on in vitro and in vivo neutral detergent fiber digestibility and rate of digestion of grass forages. J. Dairy Sci. 100:1-13. https://doi. org/10.3168/jds.2016-12364

Rahman, M. M., M. A. M. Salleh, N. Sultana, M. J. Kim, \& C. S. Ra. 2013. Estimation of total volatile fatty acid (VFA) from total organic carbons (TOCs) assessment through in vitro fermentation of livestock feeds. Afr. J. Microbiol. Res. 15:1378-1384. https://doi.org/10.5897/AJMR12.1694

Rosser, C. L., P. Gorka, A. D. Beattie, H. C. Block, J. J. Mckinnon, H. A. Lardner, \& G. B. Penner. 2013. Effect of maturity at harvest on yield, chemical composition, and in situ degradability for annual cereals used for swathgrazing. J. Anim. Sci. 9:3815-3826. https://doi.org/10.2527/jas.2012-5677

Salama, H. S. A. \& A. I. Nawar. 2016. Variations of the cell wall components of multi-cut forage legumes, grasses and legume-grass binary mixtures grown in Egypt. Asian J. Crop Sci. 3:96-102. https://doi.org/10.3923/ajcs.2016.96.102

Saunders, C. S. 2015. Growth Performance, Ruminal Fermentation Characteristics, and Economic Returns of Growing Beef Steers Fed Brown Midrib, Corn, SilageBased Diet. A Thesis of Animal, Dairy, and Veterinary Sciences. Utah State University, Logan, Utah.

Sedghi, M., A. Golian, R. P. Soleimani, A. Ahmadi, \& M. A. Aami. 2012. Relationship between color and tannin content in sorghum grain: Application of image analysis and artificial neural network. Rev. Bras. Cienc. Avic. 14:57-62. https://doi.org/10.1590/S1516-635X2012000100010

Sriagtula, R., P. D. M. H. Karti, L. Abdullah, Supriyanto, \& D. A. Astuti. 2016. Growth, biomass and nutrient production 
of brown midrib sorghum mutant lines at different harvest times. Pak. J. Nutr. 6:524-531. https://doi.org/10.3923/ pjn.2016.524.531

Sriagtula, R., P. D. M. H. Karti, L. Abdullah, Supriyanto, \& D. A. Astuti. 2016b. Dynamics of fiber fraction in generative stage of M10- BMR sorghum mutant lines. Int. J. Sci. Basic Appl. Res. 2:58-69.

Sriagtula, R., P. D. M. H. Karti, L. Abdullah, Supriyanto, \& D. A. Astuti. 2017. Nutrient changes and in vitro digestibility in generative stage of M10-BMR sorghum mutant lines. Med. Pet. 2:111-117. https://doi.org/10.5398/ medpet.2017.40.2.111

Sriagtula. R., S. Sowmen, \& Q. Aini. 2019. Growth and productivity of brown midrib sorghum mutant line Patir 3.7 (Sorghum bicolor L. Moench) treated with different levels of nitrogen fertilizer. Trop. Anim. Sci. J. 42:209-214. https://doi.org/10.5398/tasj.2019.42.3.209

Steel, R. G. D. \& J. H. Torri. 1997. Prinsip dan Prosedur Statistika: Suatu Pendekatan Biometrik. Edisi II. Terjemahan: B. Sumantri. Gramedia Pustaka Utama, Jakarta.

Supelco. 2015. Bulletin 856, Analyzing Fatty Acids by Packed Column Gas Chromatography. Sigma-Aldric.com, Bellefonte (US).

Tilley, J. M. A. \& R. A. Terry. 1963. A two stage technique for in the in vitro digestion of forage crops. J. Grassland Soc. 18:104. https://doi.org/10.1111/j.1365-2494.1963.tb00335.x
Van Soest, P. J. 1994. Nutritional Ecology of the Ruminant, 2nd ed. Cornell son, WI. University Press, Ithaca, NY. https:// doi.org/10.7591/9781501732355

Wahyono, T., I. Sugoro, A. Jayanegara, K. G. Wiryawan, \& D. A. Astuti. 2019. Nutrient profile and in vitro degradability of new promising mutant lines sorghum as forage in Indonesia. Adv. Anim. Vet. Sci. 9:810-818. https://doi. org/10.17582/journal.aavs/2019/7.9.810.818

Wang, L. W., Y. Wang, G. Wang, X. Xiong, W. Mei, A. Wu, X. Ding, Y. Li, Qiao, \& L. Liao. 2018. Effects of fatty acid chain length on properties of potato starch-fatty acid complexes under partially gelatinization. Int. J. Food Prop. 1:21212134. https://doi.org/10.1080/10942912.2018.1489842

Wu, Y., X. Li, W. Xiang, C. Zhu, Z. Lin, Y. Wu, J. Li, S. Pandravada, D. D. Ridder, G. Bai, M. L. Wang, H. N. Trick, S. R. Bean, M. R. Tuinstra, T. T. Tesso, \& J. Yu. 2012. Presence of tannins in sorghum grains is conditioned by different natural alleles of Tannin. Proc. Natl. Acad. Sci. U.S.A. 109:1028110286. https://doi.org/10.1073/pnas.1201700109

Xie, Z. L., T. F. Zhang., X. Z. Chen., G. D. Li, \& J. G. Zhang. 2012. Effects of maturity stages on the nutritive composition and silage quality of whole crop wheat. Asian-Australas. J. Anim. Sci. 25:1374-1380. https://doi.org/10.5713/ ajas.2012.12084 